\title{
The International Legal Policy in the Field of Technology Transfer and the Intellectual Property Rights: Some Controversial Issues
}

\author{
Irina V. Shugurova \\ Assistant professor of the department of civil and international private law of the Saratov State Law Academy, Saratov \\ Russian Federation, Volskaya street, 1. Saratov, Russian Federation, 410056; Email ivshugurova@mail.ru \\ Mark V. Shugurov \\ Professor of the Saratov State Law Academy, Saratov, Russian Federation, Volskaya street, 1. Saratov \\ Russian Federation, 410056; Email shugurovs@mail.ru
}

\section{Doi:10.5901/mjss.2015.v6n5s1p177}

\section{Abstract}

\begin{abstract}
The study examines the one of the dramatic collisions of international technology transfer, such as the tension between aims of technology transfer, on the one hand, and protection of intellectual property rights (IPRs), on the other hand. Authors review comprehensively the dual role of intellectual property (IP) in the international technology transfer and strive to address some of issues concerning the essence of global complex policy in area of technology transfer and of the IPR protection based on international legal instruments. The present study also deals with analysis of directions of the politics of international law in appropriate area. Authors have stressed that is important to understand that efforts of the world society to establish the international regime of technology transfer on fair and equitable terms during last 50 years presume that this regime is in conjunction with issues on the protection of IPRs. Finally, the intersecting of mission of internationally transferred technologies and aims of the IPRs protection demands a new steps of international cooperation designed to reconcile the interests of various groups of countries, interests of right holders and users of technologies. The basis of possible reconciliation is numerous provisions of international legal instruments providing for the balanced relation between perspectives of technological progress of society and interest of holders of exclusive rights.
\end{abstract}

Keywords: international technology transfer, exclusive rights, developed countries, international law, patents

\section{Introduction}

The international technology transfer is one of the significant forms of international science and technology cooperation that overlaps other forms of the latter, for example exchange of scientific information and data, exchange of specialists, supply of equipment, joint research and developments. In addition, the international technology transfer overlaps such forms of international economic cooperation as FDI and trade. Paramount technologies in conditions of transition to sustainable development around the world are characterized by the Agenda XXI (Chapter 34.3) as environmentally sound technologies (ESTs) including technologies for prevention of environmental pollutions, technologies for conservation of biodiversity and its sustainable use, as well as technologies for prevention of climate changes (low-carbon technologies or alternative technologies) or adaptation to them.

At that, internationally transferred technologies cover technologies for conservation and development of cultural heritage, exploration and exploitation of marine resources. As the result, the international technology transfer makes it possible to solve the economic, social and environmental problems worldwide. Therefore, the international technology transfer is a matter of the modern international law striving to provide and intensify the international technology transfer between different countries on the basic of appropriate and being elaborated international legal instruments. The international technology transfer faces numerous problems the solving of that is in focus of the special international legal policy, or the special politics of international law. This politics intends to improve the legal framework of the global complex policy in the area of international technology transfer and is, therefore, the indispensable conditions of the rule of law in international technological affairs closely connected with international economic affairs.

Regarded as the critical factor of sustainable economic growth and social development in whole, the international technology transfer is very sensitive to implications of protection of the intellectual property rights (IPRs), namely the exclusive rights to transferred technologies. It must be said that modern concept of technology transfer includes the 
understanding the IPRs, especially patent rights and trade secrets, and, in certain degree, the copyright addressed to the ICTs and software, in kind of necessary aspect of international technology transfer.

\section{Research Objectives}

Besides approach to the technology transfer as transfer of information and technical knowledge that are results of intellectual activity, the great significance has specifying the issue on the role of IPRs protection in the international technology transfer. We consider that the more controversial issues of relation between transfer and intellectual property (IP) at the international level deserves systemic attention as a subject matter of modern international law and its politics.

In addition, it has become increasingly clear that international legal policy in area of technology transfer and of IPRs protection is one of the precious directions of politics of modern international law. Therefore, research objectives of our study are:

- to analyze the dual role of IPRs in international technology transfer,

- to show the current approaches to coinciding IPRs protection and international technology transfer in the context of economic and technological globalization,

- to justify the significant implications of harmonized politics of international law in addressed area for using of various technologies across the world with the aim of overall prosperity.

\section{Theoretical Background}

The theoretical background of our paper is the broad vision of technology transfer. In the broad sense which is now overall the technology transfer is viewed as processes of transmitting and acquiring the results of intellectual activity not only in the national, but also in the international context. Due to technology transfer, the dissemination of ideas, knowledge, equipment, skills and, in fact, technologies takes place. The transfer of technology often is regarded to be including the absorption of new technologies and involving the concrete technological knowledge in manufacture of products. Moreover, the technology transfer enables the application of technological process and the rendering of services, granting the improvement of domestic, as well as international competitiveness in the economic market.

The next theoretical nuance is that the international technology transfer has a complex nature, being composite package containing the provisions on investments, financing capital goods, technology skills, information transfer, international scientific cooperation and other items having provided for by different international public and private arrangements at the universal and the regional levels. The success in the technology transfer requires the human resources, financial supporting, educational institutions, R\&D institutions, as well as balanced regime of IPRs protection. These important details are in focus of special directions of international cooperation.

The contemporary theoretical conception of the international technology transfer goes beyond purely economic approach. The idea of knowledge and technology as the public goods lays down in foundation of modern conception of the international technology transfer (Maskus and Reichman, 2005; Stiglitz, 1999). This idea also is a reflected in the Draft of Treaty on access to knowledge (2005). Seeking the promotion the transfer of technology and knowledge to developing countries is the core objective of this project taking into account a need of them in development of IPRs and protection thereof balanced with international technology transfer (part 3, part 4). Eventually, there are plain evidences of the formed complex global policy in the area of technology transfer and intellectual property rights (Shugurov and Shugurova, 2014). That fact presumes the special area of politics of international law, namely the international legal politics in the field of technology transfer and of IPRs protection.

\section{Methods}

During research, authors have used empirical and theoretical methods. Applied universal methods of empirical research are mainly the expert assessment and economic generalizations. First empirical method is the basis of accounting for the sophisticated complex of controversial issues of international legal policy in area of technology transfer and of IPRs protection. Second has given rise to fix the real impact of strengthening of IPRs protection on international technology transfer and, accordingly, on capacity building in developing countries.

The main theoretical methods that have been used are analysis and synthesis, induction and deduction, the system and structural analysis. As the results, there has been demonstrated conceptual framework of analyzed politics of international law and its implications for technology diffusion around the world. The principle of scientific objectivity has let to distance oneself from one-side approaches of developed and developing countries to IPRs protection in process of 
international technology transfer.

In present research other investigation methods relevant for achieving the research objectives were also applied, for example methods of comparative jurisprudence. The using of these methods has resulted in vision of feasible intersecting the international IP law and the international environmental law.

\section{Results}

\subsection{Some issues on the IPRs protection in international multilateral instruments}

The problems of international technology transfer mainly to developing countries in conjunction with objective trend of increasing of the level of IPR protection have been discussing during past fifty years. The results of these discussions are numerous bilateral and multilateral political initiatives. These initiatives have become the grounds for elaborating the legal norms laid down in national legislation and international instruments, such as various sources of 'soft' and 'hard' international law.

Anyhow, in our days, the international technology transfer is regulated not only by norms of national legislation, but also by norms of international law. The norms of public international law are addressed to states, international organizations, private sector, public institutes and individuals. In the past five decades, provisions on technology transfer have been incorporated into various international instruments, belonging to various branches of international law. These provisions imply the different objectives and scope of obligations of Contracting Parties, different modes of implementation, and are, at least, subject to different terms and conditions.

There is the array of international instruments of international law that contain various provisions, for example on financing the international technology transfer, and taking into account the complex character of technology transfer. Conventions on environment, trade, cultural and marine international law deal with specific international scientific and technologic cooperation and focus more on technology transfer as tool for capacity building in developing countries, in particular in least-developed countries (LDCs). The aim of international instruments is international legal regulation of the international technology transfer from the point of view of development. As a rule, appropriate international instruments are designed for achievement the broad goals significant for the all mankind. These instruments also intend to effective balance of interests of developing and developed countries. In sum, it should be mentioned provisions of such articles of international environmental law as, for example, Article 7a of the Convention on long-range trans boundary air pollution, 1979, Article 4.5 of the United Nations framework convention on climate change, 1992.

It is notable that, in turn, there are three main categories of intersecting technology-related provisions in broad package of international instruments in area of the international technology transfer. The first provisions concern the capacity building and solution of great number problems of development through information and technical interactions. The second provisions refer to financial and investment aspects of technology transfer related to obligations of developed countries. After all, the third provisions include standards of IPRs protection.

The specificity of given provisions enshrined in mentioned instruments is to provid for measures for technology transfer in kind of in-built mechanisms at the level of international cooperation. The issues on observance of the IPRs are here not principal and rarely mentioned. However, the strict observance of the IPRs is, in general, necessary conditions of international scientific and technologic cooperation connected with international economic cooperation. In various documents that have different international legal essence the some attention is devoted to matters on the protection of exclusive rights to transferred technologies. The certain role of this aspect is arisen from legal nature of technology transfer that is the cession of exclusive right making possible the using of variable technic and technologic innovation.

With increasing of transnational trade flows, especially flows of sophisticated production and exclusive rights to technology as result of intellectual activity, the linkage between patents and technology transfer has been getting an overarching recognition not only at the national but also at the international levels. For example, that can be seen from Article 7 and 8 of the TRIPS Agreement and Article 16 of the Convention on Biological Diversity. Other international legal instrument also contains provision on the IPRs. As it has been shown by some experts, the issues on the IPRs addressed to transfer of environment-oriented technologies are reflected in various MEAs in different ways (Martinez, 2008).

At that, the technology transfer having been recognized as the separate subject matter of Global Agenda generally, and the world economic policy and the world policy in area of aid to development in particular is one of the major concerns of the global policy of IPRs protection. It should be stressed that role of IPRs protection and enforcement thereof in the international technology transfer is core issue of global policy in area of technology transfer influencing all countries. Indeed, content, actors and trends in global policy in the sphere of IPRs concerning the international technology transfer and evolution of its agenda require to be clearly spelled out. 
The effective international legal adjusting the technology transfer should aim to succeed in arriving at goals of the latter. That posits, in the first place, the active usage all available instruments and, in the second place, the timely revealing and removing all possible legal and other barriers. The IPRs often act a legal barrier to successful technology transfer aimed at overall prosperity. There is a forthcoming a fixation of one-sided position of exclusive right possessors which restricts the transfer and diffusion of technologies. This deduction may follow from the attitude of some observers that the TRIPs Agreement, as an example, has reinforced the position of patent-holders by extremal safeguarding their legal interests and by making the confidence in that compulsory licensing would only apply in very exceptional cases. At the same time, IPRs and technology transfer proceed to be in great tensions. This show what international regime of international technology transfer remains still in progress and is far from completion, while there is the set of international instruments in which there is doing an attempt to decrease this implied contradiction and claiming the balance between the IPRs protection and the technology transfer.

\subsection{On dual role of the IPRs in the international technology transfer}

The fact of the matter is that the technology transfer in most cases is the transaction. This circumstance has yet been marked by Davison and McFetridg (Davison, McFetridge, 1984). The one of the conditions of technology transaction is, among other things, the consent of parties to protect the IPRs. The international technology transfer also, without doubt, includes commercialization of technologies in cross-boundary context. This economic facet means the transfer of research outcomes of public and private research institutions and protected results of intellectual activity of high-tech companies from one country to public institutions or private companies from other countries that make possible them to produce the commercial product for the market. The technologies as result of the intellectual activity are protected by norms of the IP law, in particular, patent law. The IPRs protection is significant condition of the technology transfer via voluntary agreements between technology holders and technology recipients.

In that way, transferred technologies, including the technology transfer with the aim of development, may be proprietary, for example, biotechnologies. This moment is taken in consideration in the pointed instruments. More so, international instruments referring to the technology transfer imply the protected and unprotected technologies. The nonproprietary technologies, or technological knowledge, as public good is used freely. They are a free of charge. This is the feature of access to them. The proprietary technologies, in essence, also are accessible, albeit the accessibility of such technologies should meet the conditions of authorization. Moreover, other array of international instruments in the sphere of international IPRs protection has underscored the moment of transfer of protected technologies. The one of the key instruments regulating the transfer of proprietary technologies is the TRIPS Agreement setting up harmonizing the minimal standards of the IPRs protection around the world.

From angle of economy, the international technology transfer is important sector of contemporary world economy the regularities of which are regularities of technology exchange. If proprietary technologies are transferred, the IPRs aspect is basic here. The transfer of proprietary technologies is transmission of exclusive rights at the national and international levels. There have arisen the global markets of IPRs in world economy. Therefore, the international system of IPRs protection and technology markets are connected very closely.

Indeed, due to extending of IPRs rules to the technology transfer, technologies understood as inventions and other protected results of intellectual activity and purchased with purpose of goods manufacturing or supporting manufacture processes, are act as commodities. Being such commodities, technologies may be transferred through commercial transactions, i.e. they may be bought, leased or solid, and, thus, have utilization and diffusion facilitated over investment, licensing or other transfer arrangements. In our opinion, the commercialization of technologies and their transferring makes the realization such goals of technologies transfer as facilitation to capacity building in developing countries very vulnerable.

As above-mentioned, there are a great number of studies and empirical generalizations of the role of IPRs protection in process of the national and international technology transfer. In spite of elaborated scientific basis of the global policy in sphere of the IP and of technology transfer conducted in framework of appropriate politics of international law, a specificity of the IPRs protection in the international technology transfer remains ambiguous and inconclusive. Said disorientates the designing and conducting of concerted global policy. The overall starting point of investigations in field of the IPRs and the international technology transfer is the recognition of dual role of IPRs. As pointed in one of the WIPO's documents, "relationship between patents and technology transfer is generally understood to have both positive aspects, namely where useful technology is indeed transferred to the recipient, and a negative component, namely where patent rights or an abuse of such rights, may equally hinder a transfer of technology".

Thus, patent licensing agreements, playing in many cases the important role, can call access to technology in 
question. However, a positive effect of patent protection of technologies on the international technology transfer and, respectively, on generating of innovation, demands that relevant jurisdiction as developed system of IP law at the national and the international levels would exist. It goes without saying, the enforcement and use of IPRs should promote the diffusion of the technology, as global goods, that they be the basis for overall prosperity. That demands the correlation the global policy on IPRs protection, global policy of development and global policy of technology cooperation.

That is very interesting the barriers of international technology transfer are not only strict but also the weak IPRs protection. The latter is one of the barriers to international technology transfer (Smith, 1999; Mansfield, 1993). Truly, technologies will not flow at great speed on waves of trade and investment in countries with the weak regime of IPRs protection where they may be imitated and used unlawfully. Bearing in mind this regularity, developing countries have gone to reforming their patent system in direction of the stronger IPRs. That gives rise more civilized form of international technology transfer. Concurrently, it is really a question of limits and nature such reforming.

The international legal policy departures from ascertained fact of the dual role of impact of IPRs on processes of technology transfer. Technologies, being results of human mind, are designed to wide use, including their use around the world. It may be possible due to international free flows of technologies. However, free flows of them demands the arranging of technology flows under legal rules. Unconditionally, the IPRs are essential for this arranging. The fact of the matter is that technologies are results of intellectual activity that should be stimulated over protection of material and nonmaterial interests of their creators that often is posing in the role of right holders.

\subsection{The IPRs and encouraging capacity building through prism of technology transfer}

The global policy of the IPRs protection and of the technology transfer is integrated with the global policy on encouragement of the international technology transfer. It sets the principle horizon of viewing the character and perspectives of IPRs influence on the international technology transfer, especially to developing and least-developed countries. The policy of transfer encouragement, beside the above-stressed, is closely connected with broader treatment of proprietary technological knowledge in the IP legislation.

The technology transfer due to significance of technologies for economy and development has become the one of the sectors of modern global economic, science and technology policy, as well as development policy. Over the years the international policies in field of encouragement of technology transfer for developing countries has arisen and now it continues to evolve. This policy is a part of world policy on international technology transfer, and it is connected with the policy in sphere of aiding to development.

In above-singed international legal documents, the right of developing countries to access to technology has been recognized. The background of international legal regulation of technology transfer is the right of developing countries to access to technology documented in them. We would like to stress that this right may be voiced as a consequent of extreme need of developing countries in obtaining the technologies, especially innovative. As one Indian expert has noted, by the technology transfer developing countries could gain the access to technologies that was new for them. Furthermore, he made as an example of East Asian newly industrialized countries that by acquisition of foreign technologies, coupled with domestic technological learning, have coped with task of accumulation of capability to change technologies (Srinivas Subbaroa, 2008). This was a crucial factor of their rapid technological and economic development connected with reaping the social benefits. The right to access to technologies should be understood as the one of the elements of right to development.

Certainly, overall statement of technology gap, on the one hand, and recognizing the right of development countries to access to technologies, on the other hand, have demanded the numerous political steps at the national and international levels to be undertaken as a response to such problem. The encouragement of technology transfer to developing countries has been permanently recurrent issue on different international economic forums, forums on aiding to development and at the level of international organizations. It is clear, adopted package of international instruments does not only regulate the international technology transfer but also contains the provisions on promotion of the technology transfer to developing countries. The promotion of technology transfer to developing countries is a subject of provisions of international, namely bilateral and multilateral international agreements on science and technological cooperation, protection of environment, as well as trade and investment.

There are two main approaches to encouragement technology transfer considering the relation between the international technology transfer and the IPRS. If to say briefly, the first approach is a regulatory, but the second is a market approach. Additionally to said, one range of experts has been focusing traditionally on market-mediated international technology transfer over trade, foreign direct investment, licensing, and personnel movements, along with informal means over imitation, reverse engineering, and spillovers. Other very justly point out the inherent shortcomings 
in technology market. It is appropriate to ask the question how should shortages of market regulating the technology transfer be defined? These shortages are inherent connection of market exchanging of technology with mass of problems, such as the asymmetric information and market power. That leads to public intervention having indispensable justifications. As Maskus considers, the IP is one of the forms of such interventions, which can support the international technology transfer, but also can create market power.

Now there are number of basic theories that demonstrate how the protection of IPRs affects the incentives for the international technology transfer. They analyze appropriate evidences of this affecting. As an example of exhaustive analysis of the comprehensive theory and real practice concerning how IPRs protection impact on encouraging of international technology transfer is Maskus's Report (Maskus, 2004). Maskus's study contains numerous suggestions for updating the incentives for encouragement of technology transfer to developing countries by policy changes in recipient and source countries, as well as in global trading system in general. Maskus's findings have been reproduced in collective research paper of experts of the World Bank (Hoekman et al., 2004). Here they have noted the capacity of the IPRs to support technology market and technology transfer. These authors have further pointed that lack of IPRs at firms would decrease their engaging to technology transactions. In other words, patents and trade secrets act as a legal basis for revealing the proprietary characteristics of technologies and making the licensing contracts, promoting increasing the technology flows to countries with appropriate technological capacity and shifting incentives for investors between FDI and licensing.

\subsection{A perspectives of coinciding the approaches of developed and developing countries to the IPRs aspects of international technology transfer}

The potential of technologies may be for much realized in global scale only in case of the effective regulation of transfer of different technologies, especially high technology, and observance of its fundamental principles, such as justice, equality, mutual advantage and reasonable terms. All countries is interested in compliance with these principles but especially developing countries most of which face problems of overcoming the technological gap between them and developed countries. The implementation of above-outlined principles and obtaining the positive impact of technology on development depend on adjusting the issues on the IPRs because they directly affect the accessibility of technologies, diffusion and follow-up usage of them.

In addition, the fact of matter is that during last 50 years, protection and enforcement of IPRs has tendency to increased standards. That implicitly diverges with the logic of technology transfer. This fact has been shown clearly by discussions at the level of international organizations and their experts. An intersecting of logic of development of technology transfer and logic of development of the international IP system is certainly in existence. But they are a coordinated and balanced not entirely. On account of that, the technology gap between developed and developing countries is not decreasing now. Quite the contrary, this gap are shaped in new forms that puts achieving the development goals at stake. This thwart with the idea of international technology transfer, namely with its mission to be tool for facilitating the access to technology for capacity building. A various multilateral agreements have been signed between countries that are at different levels of development, including different level of developing the national patent systems. Therefore, regulating the IPRs in process of transfer also refers to fundamental problem of perspectives of coinciding the interests of developed and developing countries.

The developed countries having effective system of innovation and numerous innovators have tended to set up the strong IP protection for the world in a whole through creating the appropriate standards to be implemented efficiently in the national legislations. The handful of developed countries has a real political and economic power to obtain the setting up of these standards. In contrast, other countries, namely developing and least developed, have largely focused on imitation of technology innovations as a valid source of their technological development and tended to weak protection of IPRs due to adoption of numerous flexibilities, for example, such as compulsory licenses, transitional period, parallel import. For many developing countries, the increasing of IPRs protection is perceived as the threat of shifting benefits from domestic imitation firms to foreign innovative firms, and reducing of output in domestic economy. As underlined by Deardoff, given increasing was not correlated with aims of encouraging the domestic innovative activity (Deardoff, 1992).

The modern global policy in area of IPRs and international technology transfer then focuses on possible benefits that developing countries could obtain from stronger IPRs protection. As we deem, policies of developing countries to satisfy their technologic needs by technologic imitations resting on weak IPRs protection do not orient towards long-term perspective of technology capacity building. Some experts, for example, K. Maskus argues that, in spite of dual impact of IPRs on economic development, stronger IPRs protection "can help reward creativity and risk-taking even in developing economics, with those countries that retain weak IPR protection remaining dependent on dynamically inefficient firms that 
rely on counterfeiting and imitation" (Maskus, 2000).

In other words, differently directed interests as regards IPRs protection may cause troubles for technology transfer aiming at development. In this case, provisions admitting needs of developing countries (Article 4.2. of Vienna Convention for the Protection of the Ozone Layer, Article 16 of Convention on Biological Diversity, Article 66.2 of TRIPs Agreement and so on) are far from fulfilling the goals of development. The aftermaths of collision between different group countries block the manifestations of creative potential of technologies. In our opinion, that collision impedes the transfer of environmentally sound technologies (ESTs) and put off the realization of goals of sustainable development.

The IPRs protection as significant facet of cooperation between these two parties has significant public aftermaths related to establishing the balance between interests of possessors of exclusive rights to technologies and public interests. This balance is provided by regimes of restrictions and exceptions of exclusive rights in the modern IP law. The given balance has direct relation to issues on world development. It has therefore public international aspects. The balance of interests is a serious matter of the world society that focuses on that how to harmonize the right of developing countries to access to technology in context of the right to development, on the one hand, and the IPRs that is a guard of interest of possessors of rights, on the other hand. Generally speaking, due to figure of the IP owners and the protection of IPRs in whole and patent rights, in particular, the access to using of technology is possible only through his authorization. As the result, asymmetrical relations between the technology sellers and the technology buyers derive from the IP regime that prevents using of protected exclusive rights to technology without permission of rights owners.

Consequently, the IPRs pose as possible mediums for access to technology. This medium may conduct oneself in different manner, at time acting as impediment to the technology transfer. In foundation of this problem in international aspects there mainly lay problem of contradiction between interests of developing and interests of developed countries in the area of global knowledge-based economy. Their approaches reflect a different position with regard to viewing of the role of IPR for economic development. Developed countries insist upon the positive effects of IPRs on economic development. In contrast, developing countries prefer to stress the negative effect of IPRs on economic development (Olwan, 2013).

Like collisions in the global IPRs policy, there are a different, at times opposed, approaches of given states to understanding the world development and character of supporting to it. The radical position in the global policy in the sphere of IPRs being expressed by some experts from developing countries is caused by economically oriented goals and weak connection of the system of IPRs with international system of human rights. As a consequence, the IPRs are estimated in kind of wall artificially erected against technology transfer. As K. Gopakumar considers, the complex web of IP, trade and investment has vitiated the efforts of developing countries to develop the international regime of technology transfer on fair and equitable terms (Gopakumar, 2013). While given view reflects the interests of developing countries, it should be recognized that the IPRs, in fact, is not something perfectly odious. They are indispensable aspects of the international regime of technology transfer and have certain potential for encouragement of the latter. This potential demands the appropriative coordination of international efforts on overcoming imbalanced relation between the IPRs and the transfer when exclusive rights shall promote carrying out the international technology transfer on equitable and fair terms.

It may be stressed the implementation of provisions on technology transfer means not only effective financial cooperation, but also cooperation with aim of the IPRs protection, namely realization of coordinated approach. The latter is possible if all countries will adhere to minimum standards of protection of transferred technologies. The readiness of states to take into account issues on the IPRs protection is set out in instruments of 'hard' and 'soft' international law. This also is illustrated in provisions on the IPRs protection under different agreements in the field of scientific and technologic cooperation. These provisions consolidate the approaches harmonized at the level of the global policy on IPRs protection. The given approaches are enshrined in the special IPRs protection instruments that attempt to provide the balanced relation between rights and obligations of the creators, on the one hand, and user of technologies, on the other hand, on basis of standards coordinated in them.

As we consider, the signed balance is a broad platform for the balance of interests of developed and developing countries as concerns the benefits from technology transfer. Unfortunately, this balance is rather a general aim than reality. The necessity of setting up and maintaining the just and more favourable terms of the technology transfer to developing countries spontaneously affects the issues on IPRs protection. The debatable character of the protection of exclusive rights to transferred technologies has been caused by very different interests of developed and developing countries. The first group of countries aims to pave a way of the strengthening standards of IPRs protection. The second group of countries is interested in a weak patent protection that could help them to obtain the extensible access to technologies easily. Anyway, developing countries is agreeing to protect the IPRs in framework of technology transfer process. 


\section{Discussion}

Insofar as different interests and rights in international technology transfer are affected, the relation between technology transfer and protection of the IPRs is under discussions at the level of global policy. We must be aware that the protection of the IPRs relevant to transferred technologies is one of the most controversial aspects of international legal politics in the sphere of technology transfer and its encouragement. It is determined by that the IPRs have never been more as economically and politically significant and controversial as now. Therefore, the IPRs is soundly under discussion within international cooperation concerning the technology transfer.

The IPRs is both an integral part of technology transfer law (Gutterman and Erlich, 1998) and a major aspect of technological advancement, namely the creation, adaptation, diffusion and usage of technologies that are supposed to be already in existence and emerging. Considering the issue of the IPRs impact on the international technology transfer is an integral part of proceeding debates on impact of the IPRs on development in general (Olwan, 2013; Gervais, 2007; Fink and Maksus, 2005), including economic development and growth (Falvey at al., 2006; Kumar, 2002; Khan, 2002.). The findings of empirical investigations of different aftermaths of the IPRs impact on economic growth in developed, developing and least-developed countries are the basis for understanding the tendency of impact of strengthening IPRs protection on perspectives of the international technology transfer, especially to countries with lower middle income (Sattar and Mahmood, 2011).

The technology transfer acts as extremely broad concept not referred only to aspects of IP. Butler and Gibson highlight that the technology transfer is as the dynamic area of study examining such traditional topics as IP management, risk management, market identification, role of universities, as well as the public and private labs (Butler and Gibson, 2011). However, observance of the IPRs are utmost controversial because of the licensing agreements are one of the main channels through that the transfer of technology can be carried out. Other channels of formal technology transfer, such as trade and FDI, also affect the IPRs. While, as has been stressed by Arora, the literature on international technology transfer has been growing over recent years, there remain a numerous gaps regarding the role of IPRs in technology transfer, particularly in developing countries and countries with economics in transition (Arora, 2009). That is why there is a need for further studies to understand better the impact of the IPRs on international technology transfer and to elaborate appropriate suggestions.

\section{Conclusion}

For the moment, core task of the politics of international law is the successive implementation of fundamental principles and provisions of available international instruments of international environmental and economic law, and instruments of another branches of contemporary public international law. All the more so, there emerges the global regime of IPR protection intersecting with global net of Research \& Developments and with commercialization of technological findings through formal channels of their transfer. That is why the politics of international law in area of international transfer becomes the system of initiatives covering the issues of IPRs protection. In sum, the world society is supposed to envisage harmonizing the international technology transfer and IPRs protection as one of the issues of the day from perspectives of carrying out the consistent politics of international law.

\section{Acknowledgement}

The work is conducted according to the Order of the Ministry of Education and Science of the Russian Federation for governmental works in the field of scientific activities in the framework of the basic part of the governmental task No 2014/205 "Problems of international legal policy and their influence on the national legislation".

\section{References}

Arora, A. (2009). Intellectual Property Rights and the International Transfer of Technology. WIPO, Geneva, p. 55. [Online] Available: http://www.wipo.int/freepublications/en/economics/1012/wipo_pub_1012.pdf

Butler, J. S., \& Gibson, D. V. (2011). Introduction: Technology Transfer in Global Perspectives - Issues for the Twenty-First Century. In J. S. Butler, \& D. V. Gibson (Eds.), Global Perspectives on Technology Transfer and Commercialization: Building Innovative Ecosystems (p. XIII). Cheltenham: Edward Elgar Publishing.

Davison, W. H., \& McFetridge, D. G. (1984). International Technology Transaction and the Theory of the Firm. Journal of Industrial Economics, 32(3), 253-264.

Deardorff, A. V. (1992). Welfare Effects of Global Patent Protection. Economica, 59(233), 33-51. 
Falvey, R. E., Foster, N., \& Greenaway D. (2006). Intellectual Property Rights and Economic Growth. Review of Development Economics, 10(4), 700-719.

Fink, C., \& Maksus K. E. (Eds.) (2005). Intellectual Property and Development: Lessons from Economic Research, Washington: The World Bank/Oxford University Press. [Online] Available: http://siteresources.worldbank.org/INTRANETTRADE/ResourcesPubs/ IPRs-book.pdf

Gervais, D. J. (2007). TRIPS and Development. In D. J. Gervais (Ed.), Intellectual Property, Trade and Development: Strategies to Optimize Economic Development in a TRIPS-plus Era (pp. 3-60). Oxford: Oxford University Press.

Gopakumar, K. M. (2013). Transfer of Technology and IPRs: a Development Perspective. Third World Resurgence No. 269/270, Jan/Feb 20013, pp. 6-10. [Online] Available: http://www.twnside.org.sg/title2/resurgence/2013/269-270/econ1.htm

Gutterman, A. \& Erlich, J. (1997). Technology Development and Transfer. Westport, Conn: Quorum Books, pp. 17-66.

Hoekman, B. M., Maskus, K. E. \& Saggi, K. (2005). Transfer of Technology to Developing Countries: Unilateral and Multilateral Policy Options. World Development, 33(10), $1587-1588$

Khan, B. Z. (2002). Intellectual Property and Economic Development: Lessons from American and European history. Commission on Intellectual Property Rights, Study Paper No. 1a, UK. [Online] Available: http://www.iprcommission.org/pdfs/study_papers/sp1a_ khan_study.pdf

Lo, S. T. (2004). Strengthening Intellectual Property Rights: Experience from the 1986 Taiwanese Patent Reform. Concordia University Working Paper No. 04004, Montreal. [Online] Available: http://www.international.ucl.edu/media/files/Fred_paper.pdf

Martinez, C. (2008). The Use of IP Rights in the Transfer of Technologies under Multilateral Environment Agreements (MEAs) at the WIPO Symposium on Patent Landscaping and Transfer of Technology under Multilateral Environment Agreements (MEAs) (August 26, 2008, Geneva). [Online] Available: // http://www.wipo.int/meetings/en/2008/lifesciences/ip_Iss2_ge/

Maskus, K. E. (2004). Encouraging International Technology Transfer. Issue Paper No 7. UNCTAD, Geneva. [Online] Available: Available at http://www.ictsd.org/downloads/2008/07/b.pdf

Maskus, K. E. (2000). Intellectual Property Rights in the Global Economy. Washington: Peterson Institute for International Economic, pp. $159-170$

Maskus, K. E., \& Reichman, J. H. (2005). The Globalization of Private Knowledge Goods and the Privatization of Global Public Goods. In K. E. Maskus, \& J. H. Reichman (Eds.) (2005). International Public Goods and Transfer of Technology under a Globalized Intellectual Property Regime (pp. 3-45). Cambridge: Cambridge University Press.

Olwan, R. M. (2013). Intellectual Property and Development: Theory and Practice. Heidelberg: Springer Science \& Business Media, pp. $107-110$

Roffe, P. (2001). The Unfinished Agenda. In S. J. Patel, P. Roffe, \& A. A. Yusef (Eds.), International Technology Transfer: the Origins and Aftermath of the United Nations negotiations on Draft Code of Conduct (pp. 381-406). The Netherlands: Kluwer Law International.

Sattar, A. \& Mahmood, T. (2011). Intellectual Property Rights and Economic Growth: Evidences from High, Middle and Low Income Countries. Pakistan Economic and Social Review, 49(2), 181-182.

Shugurov, M. V., \& Shugurova, I. V. (2014). Global Policy in Area of the Protection of Iprs and of the International Technology Transfer: Towards Fair Global Knowledge Economy. European Journal of Scientific Research, 126 (1), 11-33.

Siebeck, W. E., Evenson, R. E., Lesser, W. \& Primo Braga, C. A. (1990). Strengthening Protection of IP in Developing Countries: a Survey of the Literature. World Bank Discussion Paper No. 12. Washington.

Srinivas Subbaroa, P. (2008). International Transfer to India: an Impedimenta and Impetuous. Indian Institute of Management. Working Paper No. 2008-01-07. Ahmedabad, p. 3. [Online] Available: http://www.iimahd.ernet.in/publications/data/2008-01-07Subbarao. pdf

Stiglitz, J. E. (1999). Knowledge as a Global Public Good. In I. Kaul, I. Grunberg, \& M. A. Stern (Eds.), Global Public Goods (pp. 308325). Oxford: Oxford University Press.

Vivas-Euqui, D. \& Oliva, M. J. (2010). Biodiversity Related Intellectual Provisions in Free Trade Agreements, ICTSD, Issue Paper No. 4. [Online] Available: http://www.ictsd.org/downloads/2011/12/biodiversity_related-intellectual-property-provisions-in-free-tradeagreements.pdf; 